\title{
Tradeoffs of Small Scale Irrigation and Its Contribution to Land Use and Land Cover Change in Mai-Dimu, Tahtay Koraro Wereda, North-Western Tigray, North Ethiopia
}

\author{
Samuel Fissaha1 ${ }^{\text {, Fassil Kebede }}{ }^{2}$, Bobe Bedadi ${ }^{3}$, Atkilt Girma ${ }^{4}$ \\ ${ }^{1}$ Department of Water Resource and Irrigation Engineering, Aksum University, Aksum, Ethiopia \\ ${ }^{2}$ Ethiopian Environment and Forest Research Institute, Addis Ababa, Ethiopia \\ ${ }^{3}$ School of Natural Resource Management and Environmental Science, Haramaya University, Haramaya, Ethiopia \\ ${ }^{4}$ College of Dry Land Agriculture, Mekelle University, Mekelle, Ethiopia \\ Email: fisseha.sami@gmail.com,elroifky@gmail.com,bobedadi2009@gmail.com, atkiltg@gmail.com
}

How to cite this paper: Fissaha, S., Kebede, F., Bedadi, B. and Girma, A. (2017) Tradeoffs of Small Scale Irrigation and Its Contribution to Land Use and Land Cover Change in Mai-Dimu, Tahtay Koraro Wereda, North-Western Tigray, North Ethiopia. Journal of Geographic Information System, 9, 207-220.

https://doi.org/10.4236/jgis.2017.92013

Received: December 2, 2016

Accepted: December 9, 2016

Published: April 30, 2017

Copyright $\odot 2017$ by authors and Scientific Research Publishing Inc. This work is licensed under the Creative Commons Attribution International License (CC BY 4.0).

http://creativecommons.org/licenses/by/4.0/

\begin{abstract}
Improving and understanding of land use and land cover change (LULC) can help in projecting future land use dynamics and provide appropriate interventions for achieving better land management. The aim of this study is to evaluate the status of induced small scale irrigation practices that affect the different land use changes over time in mai-dimu Kebele, Tigray, northern Ethiopia. Remote Sensing (RS), Geographic Information System (GIS) were used to determine the LULC dynamics with its land cover changes (1995-2015) by dividing in to three decades. In analyzing the accuracy assessment, the Kappa coefficient was found strong agreement between classified land cover classes and observed land cover/use with greater than $80 \%$ values. The coverage of cultivated land has high land use map cover with $28.45 \%, 31.83 \%$ and $27.74 \%$ in 1995, 2005 and 2015 respectively. No irrigation practice was observed in 1995 and 2005. However, in 2015 it was covered with $1.65 \%$ of irrigated land. While the overall change difference from the year 1995 to 2015 , was also by enlarge attributed to expansion of settlement, dam, cultivated land and irrigated lands increased positively with 700.20 ha, 124.02 ha, 33.48 ha and 181.98 ha respectively which subsequently decrease the land use of grass land ( $-336.48 \mathrm{ha})$, bush land $(-561.52 \mathrm{ha})$, bare or rocky land $(-68.94 \mathrm{ha})$ and forest land $(-343.03 \mathrm{ha})$. Hence, inducing the irrigation practices could be additional yield production under dry season which later helps in improving the lively hood of the community.
\end{abstract}

\section{Keywords}

Accuracy Assessment, GIS, Kappa Coefficient, Remote Sensing, and LULC 


\section{Introduction}

Encouraging small scale irrigation (SSI) agriculture is vital to enhance production and attain food self sufficiency in Ethiopia. The success of soil and irrigation water management to maintain soil quality depends on the understanding of how soils respond to agricultural use and practices over a certain time [1].

Considering the rapid growth of the world's populations, which is in its turn a limiting factor to the arable lands around the world, the need for effective and efficient application of the crop lands have been felt more than ever [2] [3]. Hence, much attention is given to sustainable land use and improve technology, where a given land use of an area is the best in increasing crop production through supplemental irrigation [4]. Therefore, for appropriate land use and water management in irrigated area, knowledge of the chemical composition of the soil characteristics, water, climate, drainage condition and irrigation methods should be evaluated for irrigation expansion [5].

Irrigation projects mainly small scale irrigations schemes can have several environmental and social importance that may lead to the sustainable production of agricultural goods, which is of major importance and interest in the development of Ethiopia since it contributes $44 \%$ to Ethiopia's GDP, employs $80 \%$ of the labor force, and provides a livelihood to $85 \%$ of the nearly 80 million, population [6].

For different parts of Ethiopia, land use and land cover changes were studied from small scale to large scale. For example, (West Ethiopia) [7]; (North-western Ethiopia) [8]; (North Ethiopia) [9] [10] [11] [12]. All these studies show that agricultural land has expanded at the expense of natural vegetation, including forests, grazing land and shrub lands. But there is no study conducted that revealed the expansion of irrigation and its effect on the land use changes over time. Therefore, the objective of this study was to evaluate the impact small scale irrigation practices that affect the different land use changes over time in Maidimu, Tahtay-koraro Wereda, North-western Tigray.

\section{Materials and Methods}

\subsection{Description of the Study Area}

Mai-dimu micro dam (Figure 1) is found in Tabia Mai-dimu, Tahtay-koraro Wereda, North-western Tigray. It is located at $15 \mathrm{~km}$ west of Shire at $14^{\circ} 15^{\prime} 40^{\prime \prime}$ $14^{\circ} 59^{\prime} 00^{\prime \prime}$ latitude and $38^{\circ} 10^{\prime} 35^{\prime \prime}-13^{\circ} 15^{\prime} 40^{\prime \prime}$ longitude with an altitude of 2010 masl [13]. The total area of the study area (Mai-dimu and Adi-gebro) cover about 11,201.49 ha. The area lies in dry wena dega agro-climatic with diverse topographic conditions characterized with undulating terrain having step and gentle slopes. Soils are predominantly dark brown in the middle highland area and light brown and grayish color in the low land area. The mean annual air temperature was $28^{\circ} \mathrm{C}$, the maximum temperature reaches its pick during the month of April and May and annual precipitation ranges varies from $600 \mathrm{~mm}$ to $900 \mathrm{~mm}$ however there was $520.25 \mathrm{~mm}$ [14]. The rainfall season is three to four 


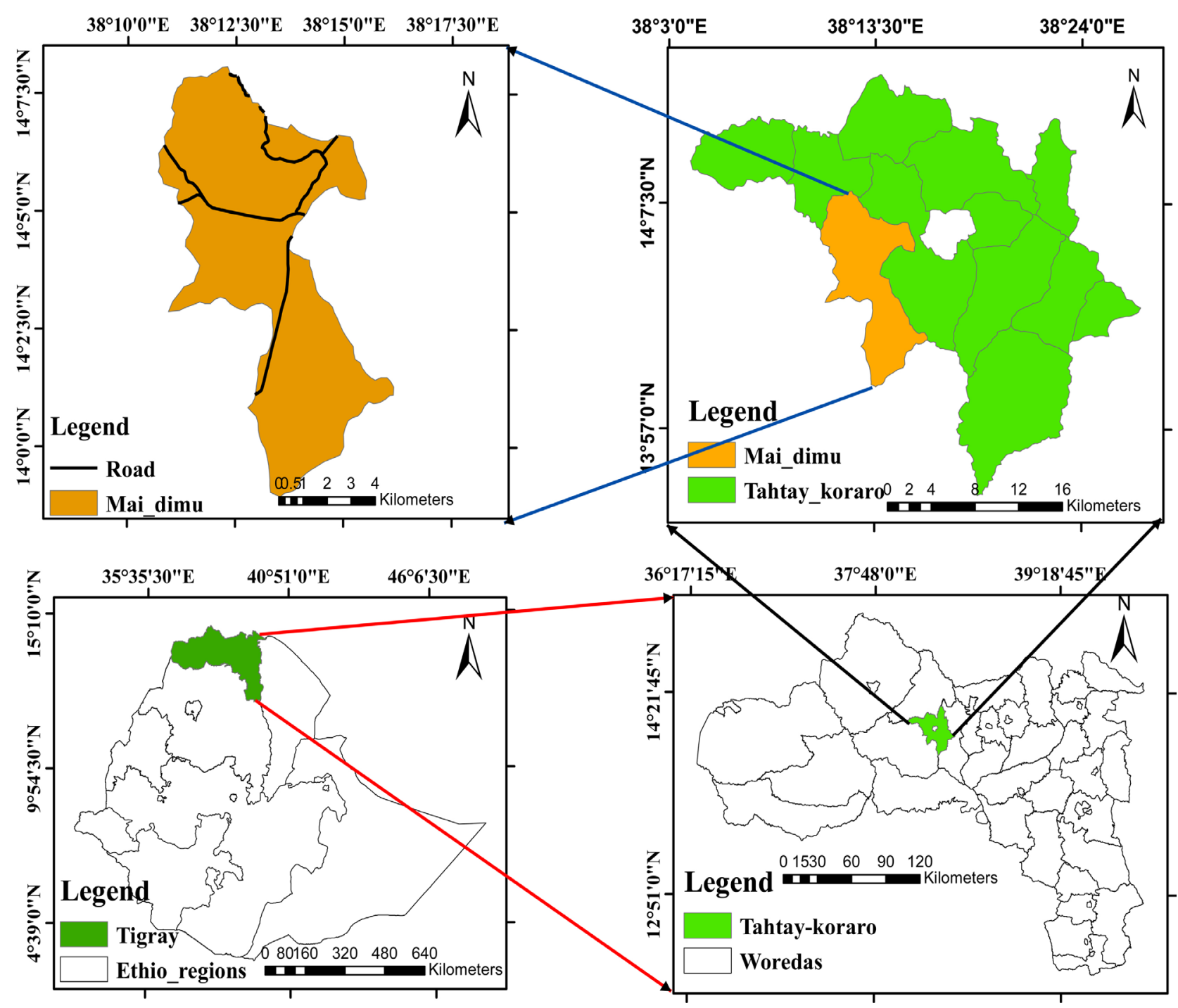

Figure 1. Location map of Mai-dimu study site.

months from June to September; and more than $85 \%$ of the total precipitation rains within these months. The rainfall is erratic in nature which imposes early, mid or late season droughts.

\subsection{Satellite Image Collection and Data Processing}

\subsubsection{Data Collection}

The location of each data points were obtained by field surveys and actual measurements using global positioning system (GPS) and camera. Secondary data were also be obtained from previous CoSAERT study reports and the nearby wereda administrative bureau for examining the history of the farming practices, type of crop grown and the area covered for irrigation after the project intervention (dam construction). In addition, various sources such as aerial photographs, topographic maps, and satellite imageries were used to generate additional data.

In addition, for collecting high quality geographic data for input to GIS, topographic maps of the scale 1:50,000 of the study areas were purchased from the 
Ethiopian Mapping Agency (EMA) and different satellite maps of the year 1995 using TM, 2005 using $\mathrm{ETM}^{+}$and 2015 using land sat 8 OLI sensors with 159 path and 50 raw having 7 bands and a pixel size of $30 \mathrm{~m} \times 30 \mathrm{~m}$ resolution imageries were down loaded from www.earthexplorer.usgs.org.

\subsubsection{Digital Image Processing}

Detailed survey were conducted in order to obtain accurate location point data for each land use change classes using the ground control points (GCP) in order to obtain the qualified and well sounded information from satellite image data for appropriate land use classification.

During data processing both data processing and interpretation were made systematically. Image interpretation phases were preceded by establishing preliminary legend [15]. While, image processing was done by two techniques called image rectification and restoration and image enhancement depending on the required correction of radiometric distortions, geometric distortion and noise[16] [17].

\subsubsection{Image Classification}

Image classifications were used in converting image data into thematic data [18]. For this study, both types of image classification systems were used named as the unsupervised classification before field visit and the supervised classification after field survey [19]. Accordingly, representative points that represent the various land cover classes were marked using GPS during field visit. These points were used to sample representative signatures for the various land cover types as (Table 1) identified during field visit and also helped for determining level of accuracy assessment.

Table 1. Land use land cover changes classes with their description.

\begin{tabular}{|c|c|}
\hline LULC Classes & LULC Description \\
\hline Forest land & $\begin{array}{l}\text { Land covered with relatively tall trees, at least have better canopy } \\
\text { coverage including integral open space and felled areas that are } \\
\text { awaiting restocking, the predominant species found in the } \\
\text { area was Eucalyptus trees }\end{array}$ \\
\hline Shrub/Bush land & $\begin{array}{l}\text { Land covered by small trees, bushes, and shrubs, and in some cases } \\
\text { such lands are mixed with grasses; It is less dense than the woodland }\end{array}$ \\
\hline Grass land & $\begin{array}{l}\text { Small grasses are the predominant natural vegetations. It also } \\
\text { includes land with scattered or patches of trees and this land } \\
\text { cover is used for grazing and browsing }\end{array}$ \\
\hline Agricultural land & $\begin{array}{l}\text { Areas allotted to extended rain fed crop production, } \\
\text { mostly oil seed, cereals and pulses are managed }\end{array}$ \\
\hline Irrigated land & $\begin{array}{l}\text { Areas allotted to extended in supplying artificial water for } \\
\text { crop production, mostly vegetables and cereals }\end{array}$ \\
\hline Bare/Rocky land & $\begin{array}{l}\text { Land, which is mainly covered by bare soil and rock out } \\
\text { crops and rock covered lands }\end{array}$ \\
\hline Settlement land & Land covered by structures, which included towns and rural villages \\
\hline Dam/Water body & Lakes, rivers, reservoirs and streams \\
\hline
\end{tabular}




\subsubsection{Accuracy Assessment Matrix}

Accuracy assessment matrix was employed to evaluate the accuracy of the classification. Based on a Rule of thumb devised by [20], we have taken 30 sample points for each land use for calculating the error matrix and these points were collected from the ground truth using the GPS and cross checked with the Google earth in acquiring the reliability of the produced map.

\subsubsection{Data Processing and Method of Producing Temporal Mapping Techniques}

The approach was done based on a combination of digital classification and visual interpretation of the images. The land use dynamics were analyzed with the continuous image analysis starting from 1995 to 2015 considering month of March or April because these months are good representative for the dry season (irrigation condition). These representative months were also supported using the ERDAS 9.2 approach which this is summarized in schematic diagram in Figure 2 shown below.

\subsection{Data Analysis}

The digital remote sensing data were analyzed, processed and geo-referenced in ERDAS imagine 9.2 software and also used for image processing to develop land use maps. Arc-GIS 10.1 was used for creating different map layers.

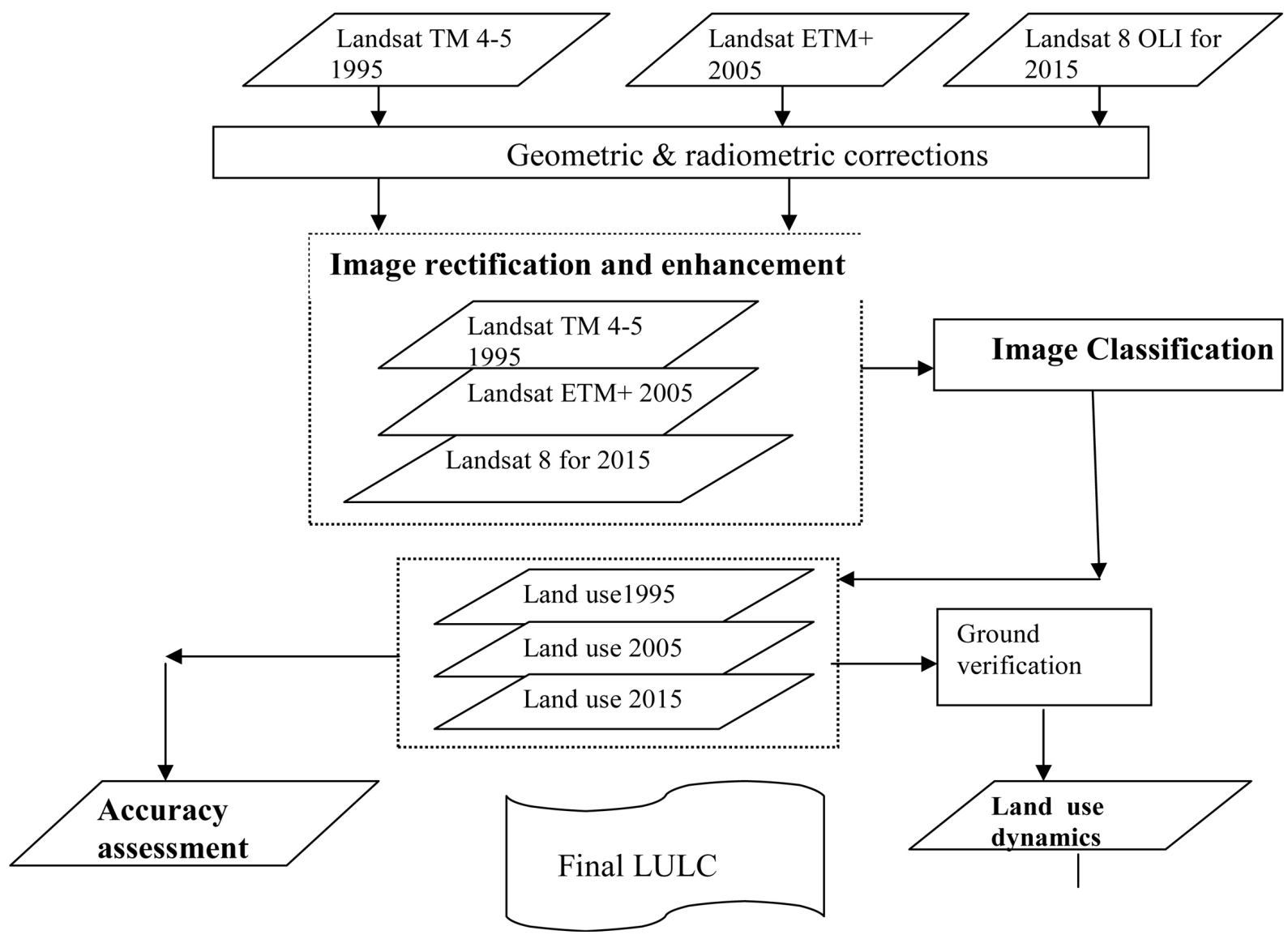

Figure 2. Schematic diagram showing the land use dynamics. 


\section{Result and Discussion}

\subsection{Accuracy Assessment for Mai-Dimu and Adi-Gebro Kebeles}

The necessary elements mainly the producer's, user's, overall accuracy and the Kappa statistics were computed. In general, the maps of the study kebeles met more than 85 percent over all accuracy (Table 2). This agreed with [21] and [22] that stated as all the output maps produced have to meet the minimum $85 \%$ overall accuracy. Moreover, the kappa coefficient of the Mai-dimu kebele (combination of Maidimu and Adi gebro kebeles) was found to be 0.81, 0.84 and 0.86 for the years of 1995, 2005 and 2015 respectively. Hence, based on these kappa coefficient results, the study kebeles have strong agreement that determines the usefulness of the map. In which this statement is supported by [23] that stated as land cover accuracy is commonly defined as the degree to which the derived classification agrees with reality and the accuracy of the map in a larger part determines the usefulness of the map.

\subsection{SSI Growth Trend Analysis and LULCC in Mai-Dimu and Adi-Gebro}

Eventhough the study area was initially focused on the mai-dimu kebele, we have faced one additional Kebele namely Adi-gebro (Figure 3). Due to, Maidimu Kebele is the source of the dam called Mai-dimu earthen dam while Adigebro Kebele is the beneficiary of the water for irrigation purposes. Therefore, the land use maps that temporarily produced were of Adi-gebro and Mai-dimu Kebeles.

Comparing the result of the study with the land cover map (Figure 3 and $\mathrm{Ta}$ ble 3), the coverage of cultivated land was found high land use map cover with $28.45 \%, 31.83 \%$ and $27.74 \%$ in 1995,2005 and 2015 respectively. This is due to agricultural land expansion together with increase the population number for increasing the annual food demand of the people. Where, [24] strengthen the

Table 2. Accuracy assessment of Mai-dimu and Adi-gebro.

\begin{tabular}{|c|c|c|c|c|c|c|}
\hline \multirow{3}{*}{ Class } & \multicolumn{6}{|c|}{ Accuracy } \\
\hline & \multicolumn{2}{|c|}{1995} & \multicolumn{2}{|c|}{2005} & \multicolumn{2}{|c|}{2015} \\
\hline & Producer's & User's & Producer's & User's & Producer's & User's \\
\hline Forest land & 84.31 & 81.89 & 82.48 & 93.51 & 92.45 & 89.24 \\
\hline Shrub/Bush land & 78.17 & 81.36 & 83.14 & 80.09 & 81.08 & 84.71 \\
\hline Grass land & 92.28 & 91.94 & 87.75 & 83.98 & 86.25 & 88.71 \\
\hline Cultivated land & 88.32 & 81.68 & 91.75 & 82.16 & 86.13 & 84.72 \\
\hline Irrigated land & 92.15 & 89.18 & 87.28 & 85.24 & 88.56 & 84.93 \\
\hline Bare land/Rocky land & 83.21 & 94.21 & 85.88 & 88.27 & 92.19 & 100 \\
\hline Settlement land & 83.49 & 97.03 & 92.18 & 88.94 & 98.28 & 94.33 \\
\hline Dam/Water body & 79.74 & 83.87 & 84.12 & 86.09 & 84.73 & 91.37 \\
\hline Overall accuracy & 86.1 & & 85.9 & & 87. & \\
\hline Kappa coefficient & 0.81 & & 0.8 & & 0.8 & \\
\hline
\end{tabular}


Table 3. LULC with its irrigation trend analysis in Mai-dimu and Adi-gebro kebele.

\begin{tabular}{|c|c|c|c|c|c|c|}
\hline \multirow{2}{*}{ Land use classes } & \multicolumn{2}{|c|}{1995} & \multicolumn{2}{|c|}{2005} & \multicolumn{2}{|c|}{2015} \\
\hline & Hectare (ha) & Percent (\%) & Hectare (ha) & Percent (\%) & Hectare (ha) & Percent (\%) \\
\hline Dam & 0 & 0 & 0 & 0 & 124.02 & 1.12 \\
\hline Grass land & 1798.65 & 16.06 & 1700.91 & 15.19 & 1802.43 & 16.09 \\
\hline Settlement & 174.69 & 1.56 & 497.25 & 4.44 & 874.89 & 7.81 \\
\hline Bush land & 2198.25 & 19.62 & 1891.35 & 16.89 & 1632.24 & 14.57 \\
\hline Cultivated land & 3231.54 & 28.85 & 3565.26 & 31.83 & 3106.89 & 27.74 \\
\hline Bare/Rocky land & 1773.72 & 15.84 & 1720.22 & 15.36 & 1704.78 & 15.22 \\
\hline Forest land & 2024.73 & 18.08 & 1827.22 & 16.31 & 1774.26 & 15.84 \\
\hline Irrigated land & 0 & 0 & 0 & 0 & 181.98 & 1.65 \\
\hline Total & $11,201.58$ & 100 & $11,202.21$ & 100.0056 & $11,201.49$ & 99.9992 \\
\hline
\end{tabular}
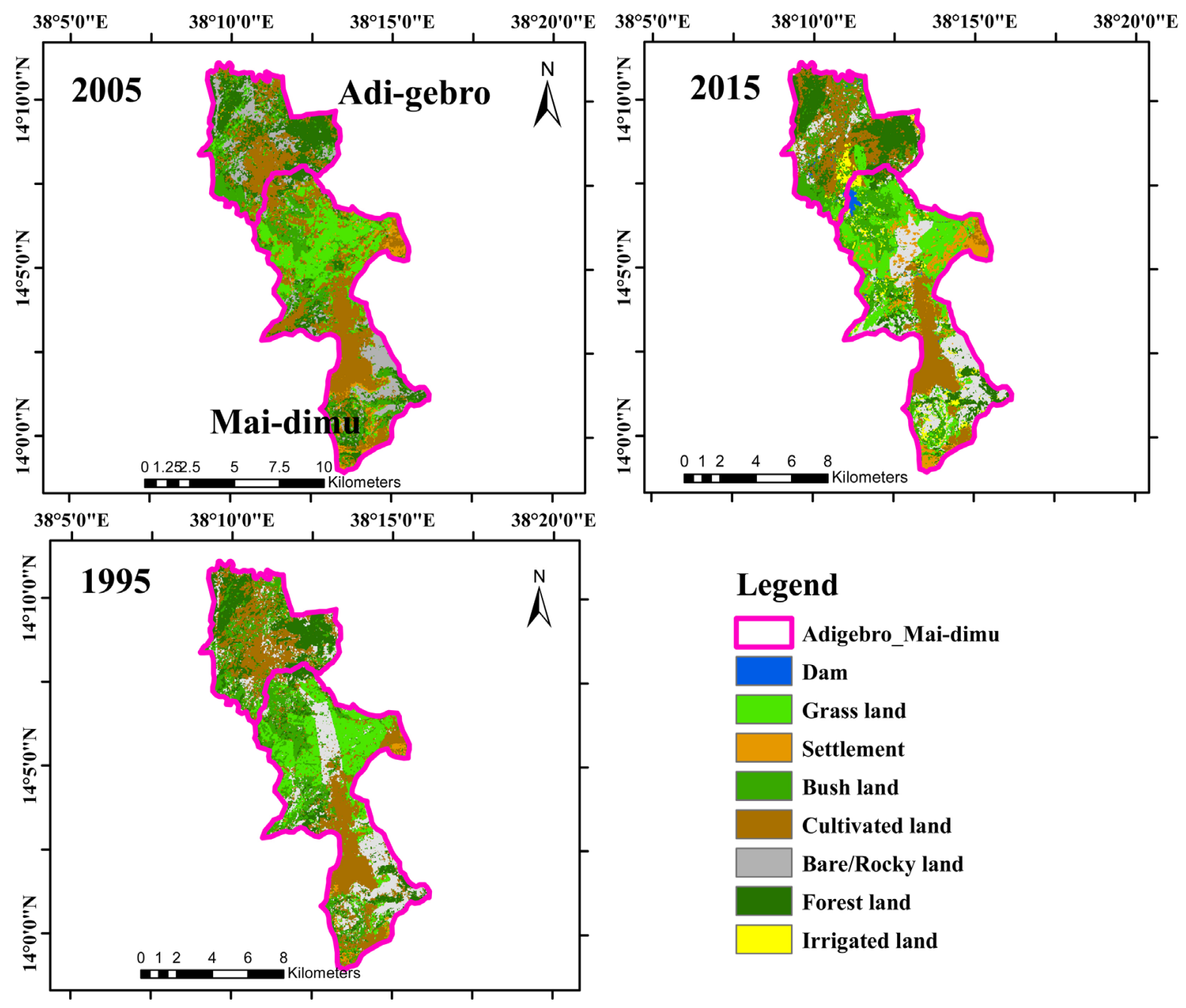

Figure 3. LULC maps of Adi-gebro and Mai-dimu kebeles.

idea as, the rural population is currently growing rapidly and consequently decrease the area under natural vegetation and its conversion in to other types of land use land cover such as agricultural and arable lands. 
Moreover, in 1995 these two kebeles have different land use classes in which $18.08 \%$ of the land is covered with forest land, $19.62 \%$ is covered with bush land, and the rest $16.06 \%, 15.83 \%, 1.56 \%$, of the land uses are covered with grass land, bare/rocky land, and settlement lands respectively. But there is no dam and irrigated land covered resulted as there were no irrigation practice in 1995.

In 2005 both kebeles also have different land use classes, $15.18 \%$ of the land is covered with grass land, $15.26 \%$ is covered with bare/rocky land, $16.89 \%$ is covered with bush land, $16.31 \%$ is covered with forest land and the rest $4.44 \%$ of the land uses is covered with settlement lands which this implied that the population number is increasing from time to time which may affect the different land use in changing from one land use to the other. But still there is no dam and irrigated land covered in 2005 which this showed that there were not irrigation practice even after ten years.

Lastly, in 2015 both kebeles also contain different land use classes, where, $1.11 \%$ of the land is covered with dam, $1.63 \%$ of the land is covered with irrigated land, $16.09 \%$ of the land is covered with grass land, $15.22 \%$ is covered with bare/rocky land, $14.57 \%$ is covered with bush land, $15.83 \%$ is covered with forest land and the rest $7.81 \%$ of the land uses is covered with settlement lands.

Overall (Figure 3 and Table 3 ) illustrated as, there is a reduction in bush land and forest land across the three mention period of land use land cover changes. This revealed that land degradation and deforestation were seriously affecting the two kebeles. As a result, the level of land productivity may decline at a faster rate and these kebeles may not in a position to sustain the annual food demand of the people. This idea strengthen by [25] that clarified as, land is also severely degraded due to unwise utilization of land resources, soil erosion, soil nutrient depletion, and soil moisture stress are the major land degradation problems that directly affect the livelihood of the society.

Besides, even though coverage of cultivated land is still covered high land use map in 2015 where agricultural land expansion is still increases, but it declines as compare to the year of 2005. This might be due to the land is changing to another land use forms mainly due to the emerge of constructing dam and exercising irrigation practices. Hence, inducing irrigation practices can be other means of changing the land use of cultivated land but this new practice encourages for solving for the food insecurity. So, implementing irrigation practices by far helps in getting additional food supplement rather than of waiting for the rainfed season only. This statement in line with [26] emphasizes the lack of certainty about rainfall, along with the raising population pressure, would require irrigation development as a primary means for future food strategies.

The land use that is covered with settlement lands increased across the three mentioned years. Therefore, the population number is still increasing from time to time which may affect the different land use in changing from one land use to the other. This concedes with [27] that stated as land cover changes are caused by a number of natural and human driving forces. Moreover, change made in LULC by population pressure can also affect biodiversity, contribute to forest 
fragmentation, lead to soil erosion, alter ecosystem services, and increase natural disasters such as flooding [28].

\subsection{LULC Detection Matrix and Its Conversion in Adi-Gebro and Mai-Dimu Kebeles}

As evident from (Table 4) land use detection matrices, there has been substantial unchanged in the area of cultivated land with 1737.27 ha during 1995-2005, although some portion of its cultivated land was converted to Dam (0.45 ha), to grass land (182.56 ha), to settlement land (206.55 ha), to bush land (267.75 ha), to bare or rocky land (412.92 ha), to forest land (389.7 ha) and to irrigated land (0.03). At the same time, it has gained areas from the classes of grass land (417.6 ha), settlement (79.67 ha), bush land (703.35 ha), bare or rocky land (344.43 ha) and forest land (117.99 ha). In this matrix table, there was not an expansion of irrigation practices starting 1995 to 2005 which irrigation practices were not implemented in these 10 years difference.

In Table 5 shown below, land use detection matrices have also been no

Table 4. LULC matrix of 1995-2005 in Adi-gebro and Mai-dimu kebeles.

\begin{tabular}{cccccccccc}
\hline \multicolumn{10}{c}{ LULC matrix from 1995 to 2005 in hectare } \\
\hline LUC & D & GL & S & BL & CL & B/RL & FL & IL & Total \\
\hline D & $\mathbf{0 . 0 1}$ & 0 & 0.01 & 0 & 0.03 & 0 & 0 & 0 & 0.05 \\
GL & 0.18 & $\mathbf{8 8 4 . 7 9}$ & 146.61 & 163.17 & 471.6 & 32.4 & 59.22 & 0 & 1757.97 \\
S & 0 & 8.01 & 49.61 & 26.28 & 79.67 & 4.32 & 28.08 & 0.01 & 195.98 \\
BL & 0 & 257.31 & 74.79 & $\mathbf{7 2 5 . 5 8}$ & 703.35 & 96.12 & 418.23 & 0 & 2275.38 \\
CL & 0.45 & 182.56 & 206.55 & 267.75 & 1737.27 & 412.92 & 389.7 & 0.03 & 3197.23 \\
B/RL & 0.27 & 339.48 & 64.53 & 222.93 & 344.43 & 544.23 & 266.85 & 0 & 1782.72 \\
FL & 0.09 & 23.67 & 45.72 & 516.51 & 117.99 & 182.81 & 1105.29 & 0 & 1992.08 \\
IL & 0 & 0.02 & 0 & 0.01 & 0 & 0 & 0.02 & $\mathbf{0} .03$ & 0.08 \\
Total & 1 & 1695.84 & 587.82 & 1922.23 & 3454.34 & 1272.8 & 2267.39 & 0.07 & $11,201.49$ \\
\hline
\end{tabular}

Where: $\mathrm{LUC}=$ Land use classes, $\mathrm{D}=\mathrm{Dam}, \mathrm{GL}=\mathrm{Grass}$ land, $\mathrm{S}=$ Settlement, $\mathrm{BL}=\mathrm{Bush}$ land, $\mathrm{RL}=$ Rainfed land, $\mathrm{B} / \mathrm{RL}=\mathrm{Bare} /$ Rocky land, $\mathrm{FL}=$ Forest land, $\mathrm{IL}=$ Irrigated land.

Table 5. LULC matrix of 2005-2015 in Adi-gebro and Mai-dimu kebeles.

\begin{tabular}{cccccccccc}
\hline \multicolumn{10}{c}{ LULC matrix from 1995 to 2015 in hectare } \\
\hline LUC & D & GL & S & BL & CL & B/RL & FL & IL & Total \\
\hline D & $\mathbf{0 . 4 5}$ & 0.18 & 1.89 & 0.36 & 0.09 & 0.27 & 0.18 & 0.27 & 3.69 \\
GL & 17.91 & $\mathbf{9 8 8 . 5 6}$ & 299.7 & 132.84 & 68.13 & 196.47 & 26.46 & 27.9 & 1757.97 \\
S & 0.81 & 17.01 & $\mathbf{7 9 . 8 3}$ & 22.95 & 42.21 & 12.87 & 14.85 & 1.44 & 191.97 \\
BL & 82.71 & 375.93 & 133.2 & $\mathbf{8 2 7 . 9 1}$ & 182.43 & 256.41 & 334.9 & 82.07 & 2275.56 \\
CL & 31.32 & 246.42 & 295.29 & 336.33 & 1563.03 & 317.52 & 383.95 & 21.23 & 3195.09 \\
B/RL & 8.73 & 187.38 & 82.26 & 188.19 & 198.9 & 778.86 & 262.44 & 36.14 & 1782.9 \\
FL & 3.33 & 47.61 & 26.1 & 365.58 & 211.86 & 156.73 & 1129.14 & 19.73 & 1990.08 \\
IL & 0.18 & 0.09 & 0.36 & 0.81 & 0 & 0.81 & 0.63 & $\mathbf{0 . 9}$ & 3.78 \\
Total & 145.44 & 1863.18 & 918.63 & 1874.97 & 2266.65 & 1879.06 & 1952.55 & 189.68 & $11,201.04$ \\
\hline
\end{tabular}

Where: $\mathrm{LUC}=$ Land use classes, $\mathrm{D}=\mathrm{Dam}, \mathrm{GL}=\mathrm{Grass}$ land, $\mathrm{S}=$ Settlement, $\mathrm{BL}=\mathrm{Bush}$ land, $\mathrm{RL}=$ Rainfed land, $\mathrm{B} / \mathrm{RL}=\mathrm{Bare} /$ Rocky land, $\mathrm{FL}=$ Forest land, IL=Irrigated land. 
change in the area of cultivated land with 1305.27 ha during 2005-2015. Although a certain part of its land was converted to Dam (84.42 ha), to grass land ( $581.76 \mathrm{ha}$ ), to settlement land ( $323.10 \mathrm{ha}$ ), to bush land (430.65 ha), to bare or rocky land (376.65 ha), to forest land (181.08 ha) and to irrigated land (170.19 ha), it has also gained areas from the classes of grass land (85.95 ha), settlement (90.27 ha), bush land (190.17 ha), bare or rocky land (316.71 ha) and forest land (278.28 ha). In contrast, there was expansion of irrigation practices starting 2005 to 2015 which irrigation practices were implemented in these 10 years difference.

Overall land use change matrices (Table 6), still there has also been unchanged in the area of cultivated land with 1563.03 ha during 1995-2015. Generally, a certain part of cultivated land was converted to Dam (31.32 ha), to grass land (246.42 ha), to settlement land (295.29 ha), to bush land (336.33 ha), to bare or rocky land (317.52 ha), to forest land (283.95 ha) and to irrigated land (121.23 ha). On the other way round, it has gained areas from the classes of grass land (68.13 ha), settlement (42.21 ha), bush land (182.43 ha), bare or rocky land (198.90 ha) and forest land (211.86 ha). Generally, there was expansion of irrigation practices and increased from time to time. Therefore, dam construction and irrigation practices in Mai-dimu and Adi-gebro was found as its infant stage where it needs more attention for using sustainably for long period of time. According to Bureau of water resource, Tigray regional office, report showed that Mai-dimu earthen dam was constructed in 2008.

\subsection{Contribution of SSI to LULCC Difference in Mai-Dimu and Adi-Gebro}

According to Figure 4, it revealed the amount of hectares that came due to the change difference from the year 1995 to 2005 . Hence, the change that was difference in LULC in the study area was by enlarge attributed to expansion of settlement and cultivated land increases positively with 322.56 ha and 333.72 ha respectively. Which this implies, agricultural expansion and the increment of

Table 6. Over all LULC matrix of 1995-2015 in Adi-gebro and Mai-dimu kebeles.

\begin{tabular}{cccccccccc}
\hline \multicolumn{8}{c}{ LULC matrix from 2005 to 2015 in hectare } \\
\hline LUC & D & GL & S & BL & CL & B/RL & FL & IL & Total \\
\hline D & $\mathbf{0 . 6 3}$ & 0.09 & 0 & 0.09 & 0 & 0.18 & 0.54 & 0.54 & 2.07 \\
GL & 12.6 & 783.09 & 257.4 & 143.28 & 85.95 & 358.29 & 32.22 & 21.33 & 1694.16 \\
S & 5.94 & 136.71 & 179.19 & 68.67 & 90.27 & 146.62 & 51.03 & 8.37 & 586.8 \\
BL & 20.25 & 193.59 & 94.59 & 789.48 & 190.17 & 264.43 & 340.92 & 30.05 & 1923.48 \\
CL & 84.42 & 581.76 & 323.1 & 430.65 & 1305.27 & 376.65 & 181.08 & 170.19 & 3453.12 \\
B/RL & 6.21 & 52.38 & 4.32 & 127.53 & 316.71 & 483.3 & 234.54 & 46.08 & 1271.07 \\
FL & 15.21 & 115.56 & 60.03 & 314.82 & 278.28 & 249.57 & 1112.13 & 122.4 & 2268 \\
IL & 0.45 & 0 & 0 & 0.45 & 0 & 0.63 & 0.09 & 0.72 & 2.34 \\
Total & 145.71 & 1863.18 & 918.63 & 1874.97 & 2266.65 & 1879.55 & 1952.55 & 189.68 & $11,201.04$
\end{tabular}

Where: LUC=Land use classes, $\mathrm{D}=\mathrm{Dam}, \mathrm{GL}=\mathrm{Grass}$ land, $\mathrm{S}=$ Settlement, $\mathrm{BL}=\mathrm{Bush}$ land, $\mathrm{RL}=$ Rainfed land, $\mathrm{B} / \mathrm{RL}=$ Bare/Rocky land, $\mathrm{FL}=$ Forest land, $\mathrm{IL}=$ Irrigated land. 
population affects the land use in one way or another which may decrease the land use of grass land (-97.74 ha), bush land (-306.90 ha), bare/rocky land $(-53.50 \mathrm{ha})$ and forest land $(-197.51)$. Therefore, expansion of cultivated land directly corresponded with the increase population pressure but inversely correlated with the greenness of the ecology.

Whereas, the change difference from the year 2005 to 2015 (Figure 5), the change that detected in LULC in the study area was by enlarge corresponded to expansion of settlement, dam and irrigated lands increased positively with 377.64 ha, 124.02 ha and 181.98 ha respectively. Which this implies, irrigation expansion and the increment of population again affects the land use which subsequently decrease the land use of grass land ( $-238.74 \mathrm{ha})$, cultivated land (-300.24 ha), bush land (-254.62 ha), bare or rocky land (-15.44 ha) and forest land (-145.52). In here, there were strongly reduction mainly in grass land, bush land and cultivated land but strongly increase in settlement and irrigation lands which gave more attention on the serious change of the land use mainly with the expansion irrigation practices that could help as means of food security.

Moreover as Figure 6 illustrated below, the overall change difference from the year 1995 to 2015 in LULC in the study area was also greatly attributed to expansion of settlement, dam, cultivated land and irrigated lands increased positively with 700.20 ha, 124.02 ha, 33.48 ha and 451.98 ha respectively. Which this implies cultivated and irrigation land expansion and the increment of population again affects the land use which subsequently decrease the land use of grass land (-336.48 ha), bush land (-561.52 ha), bare or rocky land (-68.94 ha) and

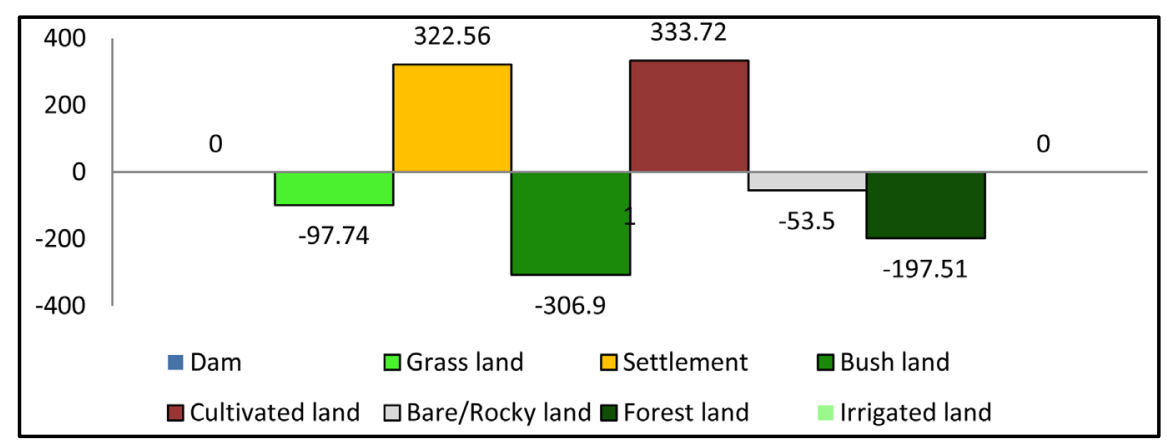

Figure 4. LULC difference of 1995-2005 in Adi-gebro and Mai-dimu kebeles.

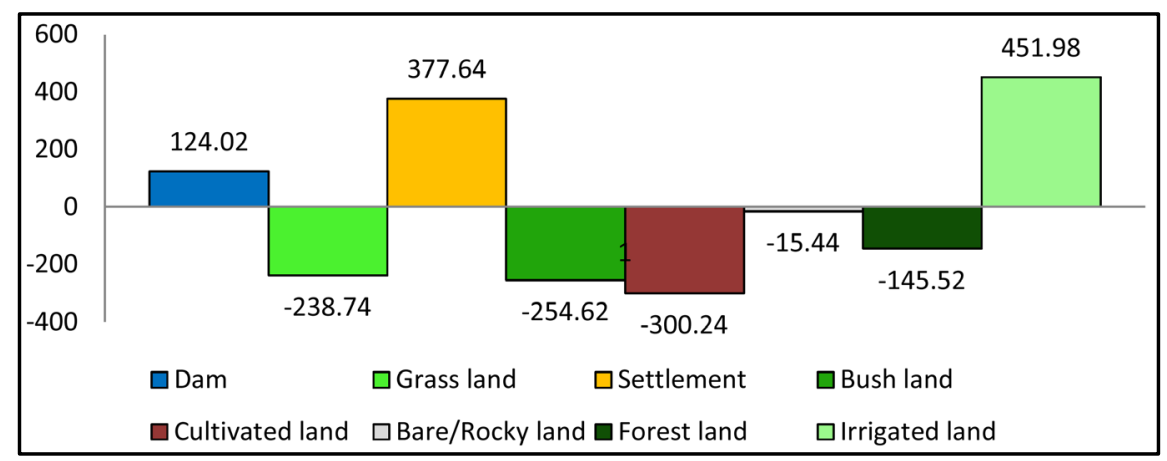

Figure 5. LULC difference of 2005-2015 in Adi-gebro and Mai-dimu kebeles. 


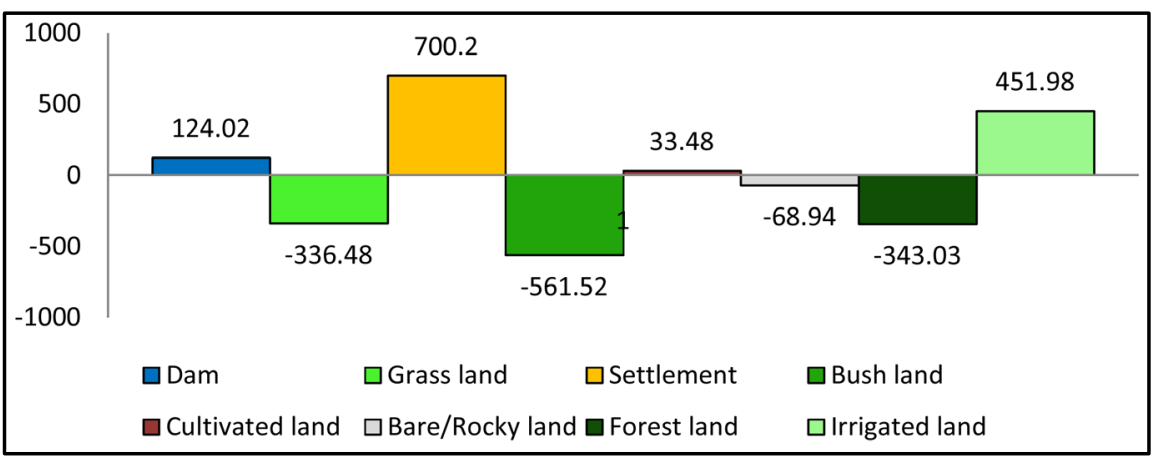

Figure 6. Over all LULC difference of 1995-2015 in Adi-gebro and Mai-dimu kebeles.

forest land (-343.03 ha).

Based on these Figures, expansion of settlements were increasing from time to time that significantly brought an effect on the sustainability of a given land use mainly forest land, bush land and grass land. This ideas in line with [29] that stated as high population pressure along with lack of alternative livelihood opportunities and sluggish rural development are causing deforestation, overgrazing, land degradation and declining agricultural productivity.

\section{Conclusion}

Land use changes and their associated management can influence soil properties and their agricultural productivity, though the amount of changes could be varied depending upon the extent of human management in all land use areas. Over all, expansion of cultivated and settlement land were the major land use and cover changes observed. On the other hand, irrigation expansion was occurred in the years of 2005-2015 land use change time frame which can show as the irrigation expansion in this study site was found at its infant stage. This irrigation expansion was held as the expense of cultivated land, bush land and forest land. The consequence of these conversion and modification processes of the land use and land cover to irrigation land and dam construction could help in increasing the additional yield production under dry season which later helps in improving the lively hood of the community living around the study sites.

\section{References}

[1] Hadgu, K.M. (2008) Temporal and Spatial Changes in Land Use Patterns and Biodiversity in Relation to Farm Productivity at Multiple Scales in Tigray, Ethiopia. PhD Thesis, Wageningen Universiteit, Wageningen.

[2] Teklu, E.J. (2005) Land Preparation Methods and Soil Quality of a Vertisol Area in the Central Highlands of Ethiopia. PhD Thesis, Universitat Hohenheim, Stuttgart.

[3] Behzad, M., Algaji, M., Papan, P., Boroomand Nasab, S., Naseri, A.A. and Bavi, A. (2009) Qualitative Evaluation of Land Suitability for Principal Crops in the Gargar Region, Khuzestan Province, Southwest Iran. Asian Journal of Plant Sciences, 8, 28 34. https://doi.org/10.3923/ajps.2009.28.34

[4] Addeo, G.G., Guasta, D. and Pisante, M. (2001) Land and Water Quality for Sustainable and Precision Farming. World Congress on Conservation Agriculture, Madrid. 
[5] Al-Ghobari, H.M. (2011) Effect of Irrigation Water Quality on Soil Salinity and Application Uniformity under Center Pivot Systems in Arid Region. Australia Journal of Basic Applied Science, 5, 72-80.

[6] FDRE (Federal Democratic Republic of Ethiopia) (2006) National Accounts Statistics of Ethiopia. National Economic Accounts Department, Ministry of Finance and Economic Development, Bairiki.

[7] Abate, S. (1994) Land Use Dynamics, Soil Conservation and Potential for Use in Metu Area, Illubabor Region, Ethiopia. African Studies Series A13, Geographica Bernensia, Berne.

[8] Zeleke, G. and Hurni, H. (2001) Implications of Land Use and Land Cover Dynamics for Mountain Resources Degradation in the Northwestern Ethiopian Highlands. Journal of Mountain Research and Development, 21, 184-191. https://doi.org/10.1659/0276-4741(2001)021[0184:IOLUAL]2.0.CO;2

[9] Belay, T. (2002) Land-Cover/Land-Use Changes in the Derekolli Catchment of the South Welo Zone of Amhara Region, Ethiopia. Journal of Eastern Africa Social Science Research, 18, 143-157.

[10] Bewket, W. (2003) Towards Integrated Watershed Management in Highland Ethiopia the Chemoga Watershed Case Study. PhD Thesis, Wageningen Universiteit, Wageningen.

[11] Hagos, F., Kruseman, G., Abreha, Z., Linderhof, V., Mulugeta, A. and G/Samuel, G. (2006) Impact of Small Scale Water Harvesting on Household Poverty Evidence from Northern Ethiopia. Poverty Reduction and Environmental Management (PREM).

[12] CoSAERT (Commission for Sustainable Agricultural and Environmental Rehabilitation in Tigray) (1999) Report on the Representative Cropping Pattern in Axum, Shire, Wukro, Adigudom and Mai Nebri. Unpublished Report.

[13] MMS (Mekelle Metorological Station) (2011) Report of Rainfall Distribution of Irrigation Command Areas of Tigray. Mekelle Meteorological Station, Mekelle.

[14] Lillesand, T.M. and Kiefer, R.W. (1994) Remote Sensing and Image Interpretation. 3rd Edition, John Wiley and Sons, Inc., Hoboken, 750.

[15] Lillesand, T.M. and Kiefer, R.W. and Chipman, J.W. (2008) Remote Sensing and Image Interpretation. 6th edition, John Wiley and Sons, Inc., New York.

[16] Lillesand, T.M. and Kiefer, R.W. (2000) Remote Sensing and Image Interpretation. John Wiley and Sons, New York, USA.

[17] Olson, J.M., Misana, S. and Campbell, D.J. (2004) Land Use Change Impacts and Dynamics (LUCID) Project Working Paper 48. International Livestock Research Institute, Nairobi, Kenya, 38.

[18] Serra, P., Pons, X. and Sauri, D. (2003) Post-Classification Change Detection with Data from Different Sensors: Some Accuracy Considerations. International Journal of Remote Sensing, 24, 3311-3340. https://doi.org/10.1080/0143116021000021189

[19] Rogan, J. and Chen, D. (2004) Remote Sensing Technology for Mapping and Monitoring Land-Cover and Land-Use Change. Progress in Planning, 61, 301-325. https://doi.org/10.1016/S0305-9006(03)00066-7

[20] Grenier, M., Labrecque, S., Benoit, M. and Allard, M. (2008) Accuracy Assessment Method for Wet Land Object Based Classification. Proceedings of the ISPRS, Calgary, 5-8 August 2008.

[21] Anderson, J.R., Hardy, E.E., Roach, J.T. and Witmer, R.E. (1976) A Land Use and Land Cover Classification System for Use with Remote Sensor Data. Us Geological Survey Professional Paper 964, A Revision of the Land Use Classification System as 
Presented in U.S. Geological Survey Circular 671, United States Government Printing Office, Washington DC.

[22] Alemu, B., Garedew, E., Eshetu, Z. and Kassa, H. (2015) Land Use and Land Cover Changes and Associated Driving Forces in North Western Lowlands of Ethiopia. International Research Journal of Agricultural Science and Soil Science, 5, 28-44.

[23] Asenafi, B. (2008) Landuse/Landcover Dynamics in Prosopis Juliflora Invaded Area of Metehara and the Surrounding Districts Using Remote Sensing and GIS Techniques. Unpubished MSc Thesis, Addis Ababa University, Addis Ababa, 88.

[24] Woldeamlak, B. and Sterk, G. (2005) Dynamics in Land Cover and Its Effect on Stream Flow in the Chemoga Watershed, Blue Nile Basin, Ethiopia. Journal of $\mathrm{Hy}$ drological Processes, 19, 445-458. https://doi.org/10.1002/hyp.5542

[25] Fitsum, H., Pender, J. and Nega, G. (2002) Land Degradation and Strategies for Sustainable Land Management in Ethiopian Highlands, Tigray. 2nd Edition, Socio-Economic and Policy Research Working Paper 25, Nairobi, Kenya.

[26] Elahi, A. (1992) Irrigation Development in Sub-Saharan Africa: Future Perspectives. In: Moigne, G.L., Ed., Developing and Improving Irrigation and Drainage Systems, Selected Papers from World Bank Seminars, World Bank Technical Paper Number 178, The World Bank, Washington DC.

[27] Liu, Y. and Chen, Y. (2006) Impact of Population Growth and Land-Use Change on Water Resources and Ecosystems of the Arid Tarim River Basin in Western China. International Journal of Sustainable Development and World Ecology, 13, 295. https://doi.org/10.1080/13504500609469681

[28] Mengistie, K., Thomas, S., Demel, T. and Thomas, K. (2013) Landuse/Landcover Change Analysis Using Object Based Classification Approach in Munesa Shashemene Landscape of the Ethiopian Highlands. Journal of Remote sensing, 5, 2411 2435. https://doi.org/10.3390/rs5052411

[29] Awulachew, S., Erkossa, T., Smakhtin, V. and Fernando, A. (2009) Improved Water and Land Management in the Ethiopian Highlands Its Impact on Downstream Stakeholders Dependent on the Blue Nile. Intermediate Results Dissemination Workshop, Addis Ababa.

\section{Scientific Research Publishing}

\section{Submit or recommend next manuscript to SCIRP and we will provide best service for you:}

Accepting pre-submission inquiries through Email, Facebook, LinkedIn, Twitter, etc. A wide selection of journals (inclusive of 9 subjects, more than 200 journals)

Providing 24-hour high-quality service

User-friendly online submission system

Fair and swift peer-review system

Efficient typesetting and proofreading procedure

Display of the result of downloads and visits, as well as the number of cited articles

Maximum dissemination of your research work

Submit your manuscript at: http://papersubmission.scirp.org/

Or contact jgis@scirp.org 